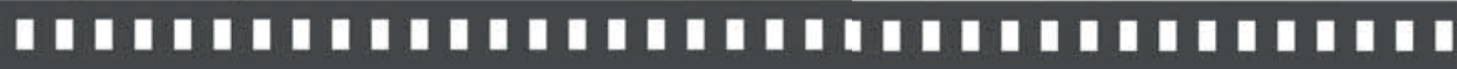

\section{Turismo e imagens: a influência do Orientalismo na construção de estereótipos}

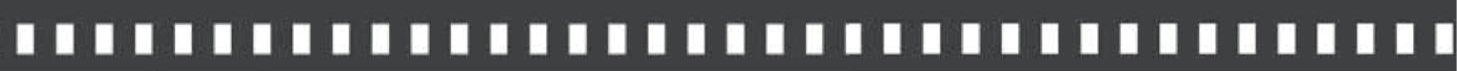

\author{
Renan Augusto Moraes Conceição
}

Rodolfo Rorato Londero

Artigo recebido em: 03/01/2018

Artigo aprovado em: 04/03/2018 


\title{
Turismo e imagens: a influência do Orientalismo na construção de estereótipos
}

\section{Tourism and images: the influence of 0rientalism in the construction of stereotypes}

\author{
Renan Augusto Moraes Conceição* \\ Rodolfo Rorato Londero
}

\begin{abstract}
Resumo: O presente artigo apresenta uma abordagem sobre o uso de imagens no turismo e sua importância historiográfica. Para tanto, a análise sustenta-se nas contribuições teóricas da abordagem orientalista, evidenciando os reflexos dos estereótipos na atividade turística e, consequentemente, na criação do fetiche na indústria do turismo. Assim, esse estudo expõe elementos teóricos para novas análises envolvendo a construção histórica do discurso turístico, especialmente sobre o uso que imagens estereotipadas podem gerar.
\end{abstract}

Palavras-chave: Turismo. Imagem. Estereótipo. História.

Abstract: This paper presents an approach on the use of images in tourism and its historiographic importance. To that end, the analysis is based on the theoretical contributions of the Orientalist approach, evidencing the stereotypes of tourism and, consequently, the creation of the fetish in the tourism industry. Thus, this study exposes theoretical elements for new analyzes involving the historical construction of tourism discourse, especially on the use that stereotyped images can create.

\footnotetext{
* Mestrando no Programa de Pós-Graduação em Comunicação da Universidade Estadual de Londrina - UEL. E-mail: renan.conceicao@hotmail.com

** Doutor em Estudos Literários pela Universidade Federal de Santa Maria. Professor do Departamento de Comunicação e do Programade Pós-Graduação em Comunicação da Universidade Estadual de Londrina.
} 
Key-words: Tourism. Image. Stereotype. History.

\section{Introdução}

O Turismo é uma área de estudo e pesquisa relativamente recente enquanto disciplina organizada. Como atividade socioeconômica, o turismo é um campo complexo de relações, gerando impactos nas áreas da economia, da cultura, da geografia, da comunicação, entre muitas outras. A partir da definição de Oliveira (2002), o turismo pode ser entendido como o conjunto de resultados de caráter econômico, financeiro, político, cultural e social produzidos pelo relacionamento dos visitantes com os locais visitados, durante a permanência desses visitantes na localidade. Desta forma, decifrar, entender e contribuir para a construção de um saber mais elaborado a respeito do turismo é uma tarefa que envolve o aprofundamento em teorias dos mais diversos campos do conhecimento, como as áreas de história, comunicação, sociologia entre outros. A interdisciplinaridade do fenômeno turístico permite a abordagem ampla e com as mais variadas perspectivas teóricometodológicas.

O turismo, enquanto atividade econômica, se utiliza de imagens, principalmente no que se refere ao uso por parte da publicidade. As imagens turísticas mostram paisagens, aspectos e singularidades de culturas específicas e, não raro, caracterizam e qualificam grandes porções de sociedades distintas dentro de um mesmo conceito imagético. Desta forma, o turismo ajuda a criar imagens e histórias similares para localidades diferentes devido 
a elas apresentarem algum traço em comum, mesmo que tênue. Essas imagens narram acontecimentos, formam representações variadas e, consequentemente, fazem parte de um discurso e de uma construção histórica.

Como as imagens turísticas são utilizadas dentro de um discurso mais amplo, elas transmitem informações a respeito de uma localidade, são recheadas de significados subjetivos, formam uma ideia geral que pode se transformar facilmente em uma visão estereotipada das sociedades e do Outro. Assim, essas imagens fazem parte de um processo de dominação do visual, da estética das localidades e das culturas como determinantes no processo turístico, culminando, então, no desenvolvimento de um fetichismo nessa atividade. Mesmo com o uso indiscriminado das imagens, o seu estudo em Turismo é um campo pouco explorado, abordado de forma não aprofundada, evitando o desenvolvimento teórico das análises apresentadas. Nesse sentido, este trabalho busca um aprofundamento que auxilie o entendimento crítico do uso de imagens na atividade turística, utilizando-se, para isso, de discussões presentes em outros campos teóricos, como a historiografia.

\section{Turismo e Imagens}

Alain de Botton (2012), um midiático filósofo suíço, escreveu o livro A Arte de Viajar, no qual desmembra o ato de viajar - e também o turismo - em aspectos diversos e distintos como a motivação, a curiosidade, a expectativa, o exotismo, entre outros. Para isso, se utiliza de relatos particulares de viagens às mais variadas localidades em conjunto com análises das viagens 
e aventuras de escritores e artistas conhecidos, dentre eles Charles Baudelaire, Gustave Flaubert, Vincent van Gogh, Alexander von Humboldt e até figuras bíblicas como Jó. Utilizando muitas imagens, o autor desenvolve a ideia de que o turismo, em suas mais diferentes formas, ajuda a desenvolver a compreensão do mundo, a expandir horizontes, a entender o outro, buscando decifrar o desejo pelo diferente. Além disso, o autor descreve a atividade turística em suas formas mais massificadas e comuns como também os aspectos específicos do estudo nesse campo, como o olhar do turista e os impactos negativos dessa indústria. É notável a forma como Botton costura referências e ilustra com vastidão de imagens uma atividade tão complexa como o turismo. Ao utilizar essas imagens, é possível verificar, nessa obra, como a união entre texto e ilustração ajuda a narrar fatos e a construir ideias a respeito de localidades turísticas de acordo com a intenção do autor.

Conforme afirma Burke (2004), o estudo da imagem como evidência histórica é recente e apenas há pouco tempo os historiadores passaram a considerar a imagem como um documento passível de análise historiográfica. No mesmo sentido, Nova (2000) aborda o uso de material não escrito na historiografia, situando no período após a segunda guerra mundial o começo da mudança de paradigma nos estudos históricos através da Nova História. Esse movimento se desenvolveu a partir da Escola dos Annales, buscando uma renovação teórico-epistemológica para os estudos desse campo, substituindo o enfoque positivista por uma variedade de áreas. Com essas reformulações, conforme explica Nova (2000), os conceitos de método, objeto e documento foram se ampliando, passando a dar espaço para a utilização de materiais e territórios 
até então não considerados cientificamente, como a oralidade, o cinema e a imagem. A autora expõe como vários estudiosos buscaram trabalhar a imagem em seus estudos, variando desde a utilização como forma a auxiliar uma narrativa histórica em torno de uma construção discursiva de relato, unificado em uma trama, presente na obra de Ricoeur, assim como a imagem em movimento, caso do cinema, e sua utilização tanto documental quanto ficcional para a investigação e exposição da história, presente na obra de Ferro (NOVA, 2000).

Tendo em vista todo esse desenvolvimento sobre o uso da imagem como base documental para a historiografia, Burke (2004) defende que as imagens em estudos históricos devem ser tratadas como fonte da mesma forma que as fontes escritas, atentando-se para alguns aspectos, como por exemplo a utilização de um conjunto de imagens e não somente uma imagem separada, bem como o cuidado de analisar o material conhecendo as fragilidades que essa fonte apresenta. Burke (2004, p. 24) assinala que "historiadores usando documentos desse tipo não podem [...] ignorar a possibilidade de propaganda, ou as visões estereotipadas do 'outro', ou esquecer a importância das convenções visuais aceitas como naturais numa determinada cultura". Com isso, é preciso estudar, acima de tudo, o criador da imagem a ser utilizada como fonte e, ainda assim, entender que, por mais confiável que o testemunho ocular (a imagem) seja, ele registra um ponto de vista, uma forma de olhar o mundo e interpretar os acontecimentos, seja em formato de pintura ou de fotografia. Ao compreender a imagem como fruto do esforço de um autor que pode estar reproduzindo nela conceitos muitas vezes inconscientes, o historiador pode expandir seus estudos e 
aumentar a percepção de fenômenos mais complexos ao analisá-lo em vários aspectos, ciente de suas limitações.

Desta forma, A Arte de Viajar é um exemplo de como é possível considerar uma imagem como fonte histórica, pois o filósofo muitas vezes recorre a explicações detalhadas de como uma pintura ou desenho representam mais do que apenas uma vista fugaz, carregando informações sobre os costumes, os pensamentos e a época do artista abordado. Ao entrelaçar as considerações sobre a vida e obra de algum artista em viagem com suas próprias experiências turísticas, Botton busca contextualizar e posicionar historicamente as imagens expostas ao longo do livro, atribuindo sentido e razões para seu uso, seguindo, de certa forma, as recomendações de não utilizar somente uma única imagem, como também se preocupa em compreender o pensamento do autor da imagem, objetivando construir sua própria narrativa turística visual.

A maneira como o turismo é exposto e analisado em A Arte de Viajar pode ser considerada como pertencente à mais comum e aceita dentro dos estudos dessa área, sem muita criticidade e posicionando o turismo como uma atividade principalmente benéfica e desenvolvimentista. Contudo, essa não é a única forma de análise do fenômeno turístico. Em seu trabalho, Ouriques (2005), antes de propor maneiras alternativas de estudo do tema, expõe as abordagens de diversos autores que se dedicaram a estudar o fenômeno turístico dentro de uma perspectiva positivista de análise, que reforça a visão economicista e ecológica do turismo na sociedade capitalista. Como exemplo desse entendimento padrão sobre a atividade turística, Ouriques (2005, p.15-16) escreve que "o turismo é associado ao tempo livre, uma [...] alternativa 
à dicotomia trabalho-ócio presente na sociedade capitalista. [...] aproveita-se o tempo livre para a evasão, para o relaxamento, para a reconstituição das forças despendidas na dura rotina do trabalho". Esse pensamento acaba por concentrar quase toda a produção científica em apenas duas formas e não desenvolve uma análise crítica acerca do fenômeno turístico.

Em concordância com esse aspecto, Siqueira (2005) critica a acepção do turismo como uma atividade essencialmente positiva, afirmando que o entendimento padrão impõe à atividade uma responsabilidade de resolução de problemas que o Turismo jamais irá mitigar. Similar à crítica de Ouriques, Siqueira (2005) posiciona o estudo científico em Turismo como exclusivamente economicista e, recentemente, preocupado com o aspecto ecológico. Essa prevalência de abordagem reitera, segundo a autora, a lógica capitalista mercantil e a busca pelo lucro dentro do fenômeno turístico, sendo necessária a relativização dessa força da mercadoria, refletindo sobre as contradições da atividade, ampliando o debate acerca do conceito e trazendo novos elementos para essa ciência. O livro de Botton, além de ser bom exemplo da análise de imagens proposta por Burke, é também representante da uma abordagem superficial a respeito do tema turismo, pois em diversos momentos o autor recorre a generalizações para expor características dessa atividade, trabalhando muito mais com estereótipos do que com conceitos bem elaborados.

Uma definição de estereótipo, mesmo que breve, torna-se importante neste momento. O sentido social e psicológico da palavra "estereótipo" remete aos estudos de opinião pública do início do século XX, mais precisamente à obra Opinião Pública, de Walter 
Lippmann, publicada em 1922. Compreendendo o estereótipo como um fenômeno da modernidade, principalmente ligado à vida “apressada e multifária” e aos meios de comunicação de massa, Lippmann (2010,p. 91) afirma que "não há tempo nem oportunidade para conhecimento íntimo. Em vez disso, observamos um traço que marca um tipo muito conhecido, e o resto da imagem preenchemos com os estereótipos que carregamos em nossas cabeças". Percebese nesta afirmação a relação sempre presente entre estereótipo e imagem, sendo reforçada pela seguinte constatação do autor: "Na maior parte dos casos nós não vemos em primeiro lugar, para então definir, nós definimos primeiro e então vemos" (LIPPMANN, 2010, p. 85). Ou seja, como um pré-conceito, o estereótipo antecipa a imagem formada pela experiência perceptiva. Também no campo dos estudos de opinião pública, Augras (1970, p. 45) reconhece duas características definidoras do estereótipo: “A primeira característica dos estereótipos é a esquematização; as características do objeto são reduzidas a uma só [...]. Em segundo ponto, o estereótipo é persistente. Do ponto de vista histórico, não é raro que permaneça durante várias gerações". Como se perceberá no próximo tópico, essas duas características estão presentes naquilo que Said (2007) chama de Orientalismo.

Burke (2004) escreve que, na historiografia, o processo de homogeneização é comum, pois é através do uso de analogias que o "Outro", essa massa de pessoas não diferenciadas, se torna mais perceptível e decifrável. No processo de compreensão quando duas culturas se chocam, a imagem que cada cultura vai formar da outra pode ser estereotipada. Burke (2004, p. 155) aponta que "a palavra ‘estereótipo’ (originalmente uma placa da qual uma imagem podia 
ser impressa) [...] é um sinal claro da ligação entre imagens visuais e mentais". Ou seja, a ideia, o conceito mental, que um indivíduo forma a respeito de uma outra cultura ou pessoa corre o risco de se moldar em um ideário genérico e não preciso. Continua o autor afirmando que, por exagerar apenas alguns aspectos, ignorando outros, o estereótipo não é de todo falso, mas o problema reside na falta de nuanças e no uso do estereótipo para agrupar uma diversidade rica de elementos em apenas uma imagem. Como exemplo do poder de discurso que o estereótipo pode gerar, Burke apresenta o Orientalismo, um conceito que engloba o emprego de imagens mentais genéricas para o entendimento de uma miríade de culturas e pessoas.

Esse conceito de Orientalismo é discutido em minúcias por Said (2007), que aborda a construção discursiva de uma ideia de Oriente, de exótico, através de diversos estudos teóricos sobre o Oriente - referindo-se, aqui, ao Oriente Médio - e também através de obras literárias a respeito desse mundo diferente do europeu. Esse desdobramento da utilização dos estereótipos será detalhado a seguir.

\section{As contribuições do Orientalismo para a análise de estereótipos no turismo}

O termo Orientalismo está intimamente ligado com a construção de estereótipos, e, mais especificamente, com o estabelecimento de diferenças primordiais entre culturas com o objetivo de subjugá-las. De acordo com Burke (2004, p. 153-154), 
No caso de grupos confrontados com outras culturas, ocorrem duas reações opostas. Uma seria negar ou ignorar a distância cultural, assimilar os outros a nós mesmos ou a nossos vizinhos pelo uso de analogia, seja esse artifício empregado consciente ou inconscientemente. $\mathrm{O}$ outro é visto como o reflexo do eu. [...] A segunda reação comum é o reverso da primeira. É a construção consciente ou inconsciente da outra cultura como oposta à nossa própria. Nessa ótica, seres humanos como nós são vistos como "outros".

Desta forma, o Orientalismo se estabelece dentro da segunda reação exposta por Burke. Ao não assimilar o Oriente como um reflexo de si, o Ocidente preferiu deixar clara a distância cultural e de costumes das culturas do Oriente Médio. Essa característica é exemplificada por Botton (2012, p. 80), ao afirmar que "o que consideramos exótico no exterior pode ser aquilo a que aspiramos em vão em casa”. Abordando o escritor Gustave Flaubert, Botton (2012, p. 80) escreve que "para entender por que Flaubert achava o Egito exótico, pode ser útil examinar, antes, seus sentimentos em relação à França. $\mathrm{O}$ que no Egito poderia parecer-lhe exótico [...] era, sob muitos aspetos, o contrário do que o indignava em casa". Esse tratamento bem delineado do Outro como completo oposto pode, conforme assevera Burke (2004), desenvolver facilmente a hostilidade, o desdém e a condescendência, aspectos aglutinados no estereótipo.

Dentro desse entendimento, Said (2007) demonstra como a imagem do oriental bárbaro, ignorante e bizarro foi construída pelos europeus ao longo dos séculos, materializando no árabe tudo o que o ocidental não queria ser, de forma bastante preconceituosa, 
acabando por se firmar como representação real e unificante de toda uma porção do globo terrestre. $\mathrm{O}$ discurso orientalista, conforme explica Said (2007) é responsável pela imensa quantidade de imagens, pinturas, desenhos, entre outras formas visuais, como o cinema, que representam o Oriente como algo parado no tempo, estático, eternamente selvagem e não civilizado. Esse conceito é, então, definido de três formas por Said (2007, p. 28): “Quem ensina, escreve ou pesquisa sobre o Oriente [...] nos seus aspectos específicos ou gerais é um orientalista, e o que ele ou ela faz é Orientalismo”, é a primeira forma, com a segunda forma sendo "[...] um estilo de pensamento baseado numa distinção ontológica e epistemológica feita entre o Oriente e (na maior parte do tempo) o Ocidente" (SAID, 2007, p. 29). A terceira definição diz que o Orientalismo é "[...] instituição autorizada a lidar com o Oriente [...] descrevendo-o, ensinando-o, colonizando-o, governando-o: em suma, o Orientalismo como um estilo ocidental para dominar, reestruturar e ter autoridade sobre o Oriente", afirma Said (2007, p. 29).

Na primeira forma, descreve-se o profissional orientalista, sendo uma definição de significadoacadêmico. Na segunda, descrevese o campo teórico, empregando um significado amplo e geral. A terceira definição considera o Orientalismo como um discurso, dando significado mais histórico e material para o conceito. Said (2007) considera imprescindível que o termo seja compreendido dentro da noção de discurso, identificando o Orientalismo como uma disciplina sistemática por meio da qual o Ocidente produziu e manejou o Oriente em todos os aspectos possíveis.

Segundo Said (2007), o Oriente não é um tema livre para o pensamento, pois nele está refletida a sua construção histórica. 
A ampla produção científica e literária a respeito desse assunto forma, sem dúvida, um cânone orientalista, mas o aspecto que torna o Oriente um tema fechado é a existência de uma rede de interesses que estará sempre aplicada quando se tratar de Oriente. Said (2007, p. 32, grifo do autor) afirma que "a relação entre o Ocidente e o Oriente é uma relação de poder, de dominação, de graus variáveis de uma hegemonia complexa, o que está indicado com muita acuidade no título do clássico de K. M. Panikkar, A dominação ocidental na Ásia". O discurso poderoso do Orientalismo, constituindo disciplina altamente organizada, em realidade, buscou impor a dominação europeia da região, pois o Oriente Médio foi uma região que não se entregou completamente ao domínio das nações imperialistas da Europa. Nesse sentido, para domesticar, na lógica de entender para dominar, mistificando esse entendimento como simples curiosidade advinda da diferença cultural, o Ocidente forjou uma ideia de Oriente, utilizando tanto conceitos quanto imagens carregadas de estereótipos grosseiros e rasos. Os europeus, sendo eles eruditos, soldados, missionários, estavam e falavam sobre o Oriente porque podiam estar e falar de lá, sem resistência alguma por parte dos orientais. A presença imperialista no Oriente, através da Grã-Bretanha e França, fez emergir uma indagação imaginativa centrada em ideias gerais sobre o que e quem era o oriental. Aliadas às abordagens mais complexas de cunho antropológico, linguístico, racial entre outras, as ideias gerais sobre o Oriente ajudaram a estabelecer o estereótipo como verdade praticamente inquestionável (SAID, 2007).

Não somente os europeus desenvolveram a noção estereotipada do oriental, mas também, já no século XX, de acordo 
com Said (2007), os norte-americanos possuem poder de dominação através desse discurso. Desde a Segunda Guerra Mundial, a Europa perdeu seu protagonismo enquanto força imperialista e essa função se transferiu aos Estados Unidos, com a diferença de que, enquanto dominador, os Estados Unidos diferem dos impérios europeus por não possuir presença real de dominação, mas sim presença virtual. Enquanto Grã-Bretanha e França estiveram dentro das nações do Oriente como reguladoras, legisladoras e comandantes, os norte-americanos se impõem através de sua influência política e comercial com países aliados a suas causas, como Israel, por exemplo. Desta forma, o discurso orientalista, sofrendo um processo de globalização através da dominação cultural americana, atinge níveis mundiais de abrangência, influenciando também países que não possuem ligações diretas com o Oriente. No decorrer de toda a explanação sobre o Orientalismo, Said (2007) demonstra como essa imagem estereotípica perdura até a atualidade e as diversas formas que os temas orientalistas estão inseridos no pensamento moderno ocidental.

Essa análise histórica sobre o surgimento do Orientalismo enquanto forma de estereótipo converge com o raciocínio de Burke (2004), ao analisar que um dos problemas da imagem como documento é o foco no típico em detrimento do individual. Conforme já exposto, o estereótipo evidencia apenas alguns traços e ignora outros, buscando reforçar a tipicidade de alguma cultura. Desta forma, aquilo que é considerado típico pode ser o resultado de extensa observação, como pode ser também uma interpretação rasa ou preconceituosa. Novamente, é possível demonstrar esse aspecto através de A Arte de Viajar quando o autor discorre sobre 
um dicionário de ideias feitas escrito por Flaubert para catalogar os preconceitos presentes na sociedade europeia da época: "mulheres de harém - todas as mulheres orientais moram em haréns" (FLAUBERT apud BOTTON, 2012, p. 81). Passagens como essa, na obra de Flaubert, demonstram a visão estereotipada que os europeus tinham a respeito da cultura oriental, considerando-os como nãocivilizados, despudorados, animalescos, completo oposto da cultura ocidental europeia. Portanto, as ideias e imagens estereotipadas fornecem muitas informações e evidências que devem ser levadas em conta. Burke (2004) considera que as imagens, carregadas ou não de visões preconceituosas, documentam muito bem o encontro cultural e as reações dos indivíduos pertencentes a essas culturas em choque. Através das imagens e do processo de realização dessas imagens, é possível detectar de qual forma as culturas estão compreendendo a outra, se de forma espelhada ou repulsiva.

Entretanto, existem estudos e áreas de pesquisa, como o Turismo, que buscam evidenciar o uso positivo dos estereótipos. Pereira e Ornelas (2005) abordam a questão buscando uma resposta para a dúvida do uso pragmático dos estereótipos, que contribuiria para alguns segmentos sociais ou até mesmo para a sociedade como um todo. Os autores, mesmo considerando que o estereótipo codifica informações e categoriza socialmente os indivíduos, analisam o emprego dessas imagens pela indústria do turismo. Pereira e Ornelas (2005, p. 10) entendem que "talvez nenhuma condição da vida cultural moderna seja capaz de salientar a natureza utilitária dos estereótipos quanto a indústria do turismo". A premissa é a de que, como os estereótipos existem e eles carregam conceitos preconceituosos ou generalizações rasas, deve haver algum aspecto 
positivo que possa minimizar seus impactos negativos. Assim, os autores assinalam que a motivação da viagem não é mais baseada unicamente na procura por paisagens exuberantes ou históricas, mas envolvem "[...] o encontro com pessoas diferentes, com práticas pouco usuais, costumes exóticos e hábitos distintos [...]. Conceitos como o de turismo étnico [...] se referem a esta apropriação dos componentes positivos dos estereótipos" (PEREIRA; ORNELAS, 2005, p. 10). O exótico ganha espaço como fator de motivação para a realização do turismo. Dentro dos estudos em Turismo, de acordo com as críticas de Ouriques (2005) e Siqueira (2005), essa forma de abordagem otimista da atividade é a mais recorrente. Pereira e Ornelas (2005) enfocam a busca por algo positivo do estereótipo e não abordam com criticidade os certeiros malefícios que essas imagens causam. Em um trecho, os estudiosos apresentam o uso de estereótipos na indústria turística:

Em que medida podemos afirmar que os estereótipos contribuem para o fomento do turismo? Como eles são utilizados pelas agências de fomento para promover o turismo? Os materiais promocionais elaborados pelas agências de fomento ao turismo procuram divulgar e promover os destinos, utilizando os estereótipos como um meio de ressaltar aos olhos do curioso o que aquele destino tem de mais relevante, belo, atraente, sedutor e encantador, desempenhando o papel de formador de motivações e desejos, permitindo a construção da identidade turística do destino que está sendo promovido. A utilização dos estereótipos no turismo pode ser entendida como uma tentativa de identificar como muitas representações são criadas, compartilhadas e difundidas mediante o uso dos meios de comunicação para vender um destino, estratégia essa em que poderosas ferramentas na divulgação, 
promoção e marketing se aliam a um conjunto de representações existentes no repertório coletivo, permitindo o desenvolvimento deste segmento da economia de forma cada vez mais profissional (PEREIRA; ORNELAS, 2005, p. 11).

Essa abordagem do tema é bastante significativa, expondo a predominância do entendimento economicista dentro da teoria turística. Mesmo com todos os problemas já abordados sobre o estereótipo e seu poder como discurso, originando até mesmo conceitos como o Orientalismo, o estudo em Turismo se volta ao benefício econômico que uma imagem carregada de generalizações pode ter. Relativizando e até mesmo ignorando que o uso de estereótipos pode gerar uma relação de poder e dominação de determinadas culturas ou regiões perante outras, Pereira e Ornelas qualificam que a existência dessas imagens permitem a construção de identidades turísticas. Como bem demonstra o Orientalismo, essa característica é, em realidade, muito insidiosa. Conforme explana Said (2007), o uso sistemático desse recurso já é feito desde o século XVIII, no que se refere ao Oriente Médio, e a identidade do Oriente foi e é mediada até hoje com exclusividade pelos europeus e norteamericanos, não sendo de fácil acesso a apreensão da identidade local pelos próprios orientais. A visão otimista dos autores em Turismo, que enfatiza o uso comercial e o teor capitalista dos estereótipos, estigmatiza ainda mais o que é considerado exótico aos olhos do turista.

Nesta perspectiva, Urry (2001) traz algumas considerações a respeito do olhar do turista. Afirma o autor que não existe apenas um olhar do turista, mas variados olhares que são construídos social e historicamente. De forma geral, o olhar do turista se volta 
para aquilo que se situa fora da esfera habitual de vivência. Assim, aspectos da paisagem, das pessoas e da cultura que se distanciam da experiência cotidiana formam a base para a motivação de viagem. O olhar do turista também está envolto na expectativa que uma determinada localidade gera no âmbito da motivação, pois essa expectativa é fomentada, mantida e reforçada através de diversas práticas não turísticas, como o cinema, a fotografia, a televisão, a literatura entre outros. Desta forma, o olhar do turista se atrai muitas vezes para o que é considerado típico de uma determinada localidade e cultura. Urry (2001) localiza essa busca por uma característica típica de certa localidade com o desejo pelo exótico, apoiado pela expectativa de vivência de fantasias e prazeres intensos que se opõem à vida comum. Com isso, o exotismo pode facilmente se basear em interpretações apressadas e em estereótipos quando ele se perpetua através do olhar do turista. É possível afirmar, então, que o olhar do turista se volta sempre para imagens que possam materializar uma ideia, uma expectativa. Botton (2012) sintetiza essa característica ao descrever sua viagem à Barbados. Motivado por obras de arte retratando o Caribe e por panfletos de uma agência de viagens, ao se encontrar pessoalmente no destino turístico, o autor se deparou com uma profusão de elementos que não haviam aparecido em nenhuma imagem publicitária e, consequentemente, em nenhuma imagem imaginária criada pela expectativa, como, por exemplo, postos de gasolina, outdoors comerciais e fábricas diversas, itens comuns da vida cotidiana de uma cidade. Escreve Botton (2012, p. 20) que, "se havia algum problema com essa profusão de imagens, era que elas tornavam estranhamente mais difícil ver a Barbados que eu fora descobrir”. Em um trecho que 
engloba exemplarmente a imagem estereotipada, Botton (2012, p. 21) expõe que,

Se nos sentimos inclinados a esquecer quanto existe no mundo além daquilo que antecipamos, talvez a culpa seja um pouco das obras de arte, pois nelas encontramos o mesmo processo de simplificação ou seleção que e manifesta na imaginação. As impressões artísticas envolvem uma redução severa daquilo que a realidade nos impõe.

Não somente as impressões artísticas reduzem severamente os aspectos da realidade, mas as fotografias e as imagens em geral podem ter esse efeito quando focadas, insistentemente, em apenas alguns traços da realidade, conforme já abordado ao longo do presente estudo. Dentro desse contexto, as imagens turísticas acabam se impregnando, pela publicidade, de representações reduzidas das localidades, esvaziando suas características históricas. A esse debate, Moesch (2001, p. 46) contribui afirmando que "as imagens geradas pelos diferentes olhares dos turistas passaram a constituir um sistema de ilusões, que se autoperpetuam e proporcionam ao turista uma base para que ele selecione e avalie os lugares potenciais que visitará, o que não significa vivenciar a realidade [...]". Ou seja, a imagem estereotipada permite o julgamento antecipado do turista, podendo gerar mais generalizações e preconceitos. Dias e Cassar (2005, p. 164) expõem que "o turismo é fortemente influenciado pela imagem de marca das cidades, em que os estereótipos ocupam um grau importante, acompanhado dos estilos de vida e das experiências anteriores de outros consumidores", sendo possível observar como o conceito de Orientalismo reflete na atividade turística. 
Como a experiência anterior de outros viajantes influi nas expectativas e nas experiências futuras de novos turistas, uma instituição como o Orientalismo, com a abrangência e poder explanados por Said (2007), pode moldar a imagem turística do Oriente com facilidade. Devido à potência de seu discurso, construído desde o século XVIII, viajantes motivados por obras de arte, filmes e fotografias do Oriente, em realidade, construíam e constroem suas expectativas de viagem baseados em generalizações culturais e preconceitos. O Orientalismo, de fato, fornece subsídios para a existência de discursos dominadores em todas as localidades que possam ser consideradas exóticas e diferentes da dominante europeia-norte-americana. Culturas diferentes e que não podem facilmente ser entendidas por um processo de espelhamento, passam a ser entendidas e dominadas por uma inversão, representadas como o oposto da cultura dominante. E, com efeito, o turismo se utiliza desse entendimento. A seguir, serão expostas algumas imagens e textos sobre viagens em países do Oriente Médio.

No site Guia Viajar Melhor, em artigo intitulado "Viajando Para o Egito: lugares surpreendentes para conhecer no país", encontra-se:

Uma terra recheada de história, mistérios e superstições o Egito deixou de ser um destino conhecido só por arqueólogos há um tempo e vem crescendo cada vez mais com o turismo. A exótica Cairo é a porta de entrada do país, caótica e barulhenta a cidade oferece alguns dos melhores museus do mundo, com esculturas, sarcófagos e outras preciosidades do Egito, como as Pirâmides de Gizé, distante a apenas $18 \mathrm{~km}$ do centro do município (VIAJANDO..., 2017). 
O texto, sempre aludindo ao teor exótico da localidade, é ilustrado com fotografias de locais religiosos e antigos. Abaixo (Figura 1), uma das imagens utilizadas e que exemplifica todo o exotismo do Egito, segundo o site, mostrando a cidade do Cairo.

Figura 1 - Vista da cidade do Cairo

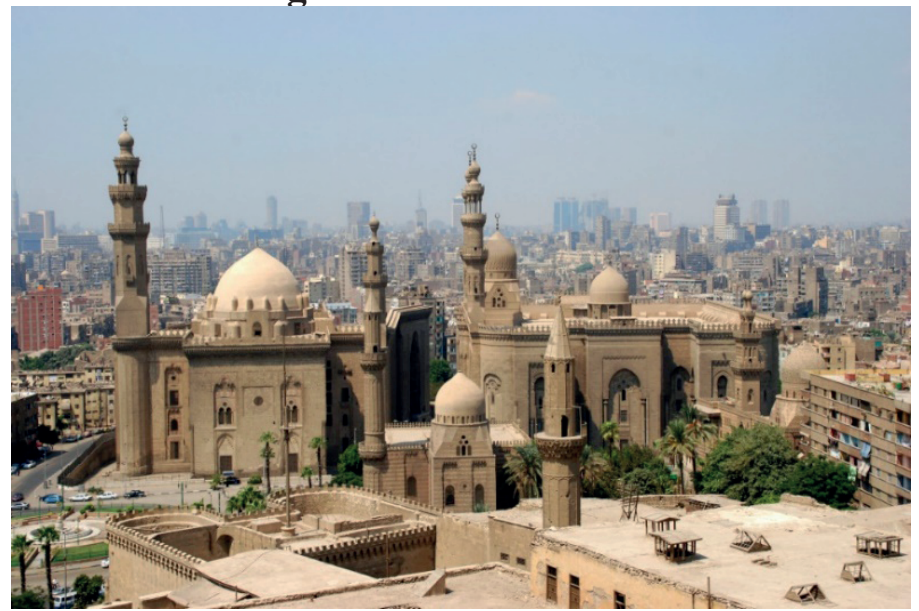

Fotografia: Marco Boekestijn

Fonte: Viajando... (2018).

O teor exótico é identificado, no texto, pela mistura de estilos arquitetônicos antigos com modernos, na religiosidade de templos e mesquitas em meio ao cotidiano caótico de uma metrópole. $\mathrm{O}$ artigo do site contém, também, fotografias das pirâmides, camelos e de grandes mesquitas muçulmanas. Essa é uma apresentação muito comum do Egito em encartes turísticos e, também, em toda a literatura já produzida sobre o país, conforme apresentou Said (2007). Botton (2012) também abordou essas características ao relatar sobre o trabalho de Delacroix e Flaubert, utilizando imagens muito similares a essa fotografia. Adiciona-se 
a isso toda a produção de Hollywood nos mais diversos filmes e o que se obtém é uma imagem única e estática sobre o Egito, em que o antigo é indissociável da vida moderna comum.

Em outro website, mochilando.com.br, é possível encontrar uma série de artigos que relatam sobre o Oriente Médio, entre eles, Por Que Viajar Para o Irã. Madureira (2016b), a autora, expõe uma série de razões para a realização de uma viagem ao país, relatando sua própria jornada e utilizando muitas imagens para ilustrar o texto. A Figura 2 é uma das imagens, mostrando um mercado público oriental.

Figura 2 - Mercado público iraniano

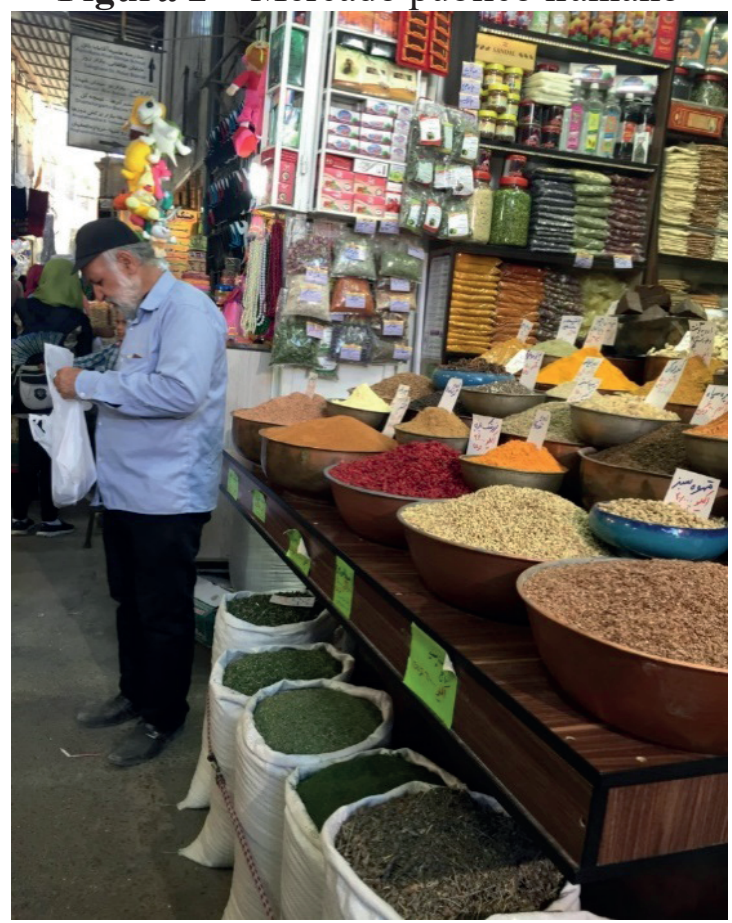

Fotografia: Fernanda Madureira

Fonte: Madureira (2016b) 
O exemplo do bazar iraniano é utilizado como demonstrativo da cultura local, conforme escreve Madureira (2016b): "ir ao bazar é vivenciar o dia a dia e a cultura iraniana". Observando atentamente a fotografia, existem elementos comuns que bem poderiam representar um mercado público em qualquer país, similar aos existentes em diversas cidades até mesmo no Brasil, mas a fotografia encaixada dentro de uma lista de motivos de viagem sobre um país do Oriente Médio adquire significados diferentes, sendo que uma possível intenção da imagem é a de capturar o exotismo de um "mercado de especiarias", razão para uma visita turística. Em outro artigo para o mesmo site mochileiros. com.br, "O Que Fazer no Irã: descubra o que é indispensável em uma visita pelo país", Madureira (2016a) recorre a um tipo comum de texto turístico, encerrando em quatro ou cinco exemplos tudo o que é importante no país visitado. Entre os itens do que é relevante, a autora destaca a religiosidade, os costumes islâmicos. Abaixo (Figura 3) uma das mesquitas apresentadas como ponto turístico obrigatório, a Mesquita Rosa. 
Figura 3 - Interior de mesquita iraniana

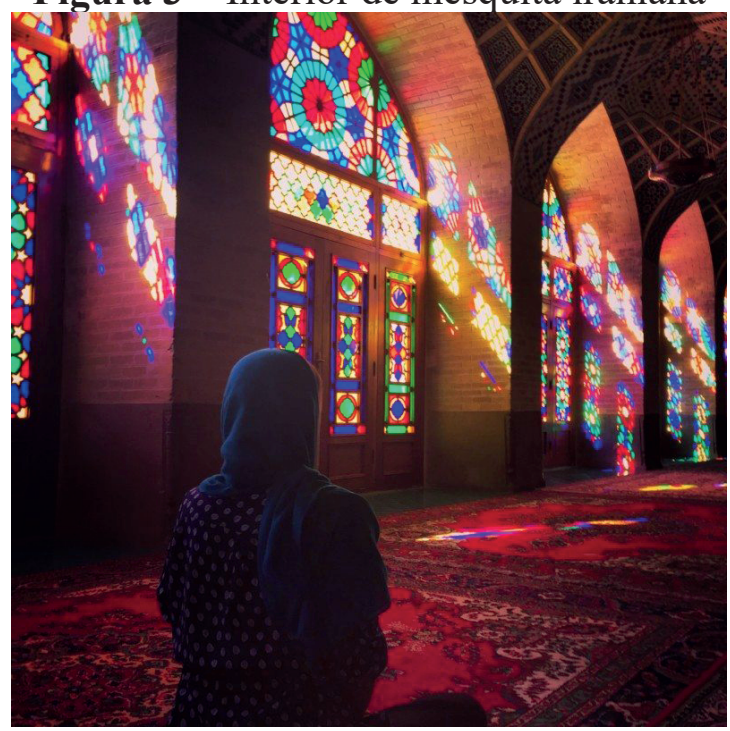

Fotografia: Fernanda Madureira

Fonte: Madureira (2016a).

Tanto a Figura 2 como a Figura 3 são utilizadas para demonstrar que o Irã é um país turístico e seguro, fugindo do estereótipo moderno do Oriente Médio, pautado pelos Estados Unidos como região terrorista. Madureira (2016a) aborda isso claramente:

Toda vez que eu contava para alguém que iria conhecer o Irã na minha viagem de volta ao mundo eu escutava as seguintes frases: - Você é louca! Fazer o que no Irã? - Irã? Mais (sic) lá só tem terrorismo! - Tanto lugar para conhecer e você quer ir lá fazer o que? - Vai ter que usar burca hein? - Eu hein, aquele povo estranho [...] Não foi fácil lidar com tantos comentários negativos a respeito desse país incrível, mas segui meu coração, encarei a cara feia e lá fui me aventurar! 
Assim, ao utilizar as fotografias da viagem, entre elas as duas aqui expostas, a autora objetiva desmitificar a opinião geral sobre a localidade. $\mathrm{O}$ discurso orientalista atual, dominado pelos Estados Unidos, mas exportado através de filmes e outras representações pela indústria cultural norte-americana, é absorvido por nações que não se relacionam diretamente no cenário político, como o Brasil, tendo, por consequência, impregnado de ideias orientalistas a visão de brasileiros. Porém, ao demonstrar que o Irã não é o que o estereótipo difunde, Madureira também propaga a ideia orientalista, se valendo das mesmas narrativas que foram muito utilizadas desde o Século XVIII por escritores e artistas. Apontando o que é diferente como exótico, belo e atraente, a mesma generalização realizada séculos antes é feita na atualidade. As imagens escolhidas pela autora para ilustrar seu relato mostram características tidas como típicas de lugares exóticos, como a arquitetura, o design das janelas, o comércio em estilo antigo, o véu muçulmano sobre a cabeça. Igualmente, a fotografia do Cairo traz a mesma abordagem, e em muitos outros websites e blogs de viagem, ao se falar sobre o Oriente, as imagens terão o mesmo teor.

No âmbito da publicidade turística, a prevalência de imagens estereotipadas é ainda maior, pois, diferentemente de relatos em sites e blogs, onde a preocupação é a formação de uma narrativa turística, há a intenção de se vender o destino como mercadoria. No turismo, é o estereótipo que atrai a atenção do turista, conforme Urry (2001) demonstrou, com o olhar do turista se voltando incessantemente para os elementos típicos das culturas diferentes, e os encartes de agências de viagens e grandes operadoras de turismo evidenciam esses elementos. 
Nesta perspectiva, o uso de imagens no turismo e a construção discursiva do exótico através de estereótipos, como é possível observar na produção publicitária turística, nada mais revelam do que o caráter fetichista dessa atividade. Os destinos turísticos passam a ser mercadorias e, como tal, devem ser vendidas em razão do lucro. Por se configurarem como mercadoria, a aparência desses destinos, a estética dessas localidades - bem como das imagens que a representam, passam a ser um vetor importante no processo de venda. Conforme escreve Haug (1997), a estética da mercadoria é utilizada com muita ênfase no mundo atual, transformando as relações de troca em relações pautadas pela aparência. A estética da mercadoria contribui, assim, para a criação do fetiche, para a dominância da mercadoria em todos os aspectos vividos, mostrando o mundo da mercadoria como ele é. No mesmo sentido, Debord (1997) afirma que o fetiche é a dominação da sociedade por uma seleção de imagens, a dominação do parecer, da aparência, em detrimento do ser. Para isso, há a predominância das imagens sobre a realidade, a predominância da visão no mundo. A isso ele chamou de espetáculo, afirmando que as sociedades atuais vivem dentro dessa condição. Assim, o espetáculo é a predominância do fetiche na vida das sociedades, e o fetiche é construído a partir da estética da mercadoria, isca para atrair compradores a fim, unicamente, de realizar a mercadoria como valor de troca e não como valor de uso.

O turismo, nessa ótica, é apenas um dos muitos componentes do espetáculo, uma atividade altamente fetichista, onde a estética da mercadoria esvazia completamente o valor de uso em razão da aparência. Conforme Urry (2001), o olhar do turista é 
uma das causas da redução de destinos a estereótipos que possam ser vendidos como souvenirs, e essas lembranças de viagem passam a dominar as intenções dos turistas, parecer em detrimento do ser, colecionar destinos e não vivenciá-los.

\section{Considerações Finais}

O Turismo, como campo de estudo recente e buscando um corpo teórico que o justifique como disciplina científica, baseia-se muito em posições pouco aprofundadas de estudo e análise, tendendo a se aceitar como simples componente da dominação capitalista. Desta forma, os teóricos da área realizam suas contribuições mais em uma posição reformista do que crítica desse fenômeno. Ouriques (2005, p. 26) afirma que o estudo do turismo "acabou trilhando os caminhos fáceis e obscuros do pós-modernismo, que se caracteriza pelo desprezo às tentativas de teorização geral, pelo abandono [...] das grandes teorias explicativas da sociedade, pela proclamação do 'fim da história' e dos paradigmas". Com isso, o aprofundamento em campos teóricos diversos e o estudo crítico do turismo é cada vez mais necessário para solidificação do conhecimento sobre essa atividade que é cada vez mais comum nas sociedades atuais.

Relacionar o turismo com a escrita da história através de imagens contribui para a compreensão do poder que o estereótipo causa no fenômeno turístico, e analisar esse aspecto tendo como exemplo o Orientalismo, uma construção narrativa histórica e imagética, sem dúvidas, ajuda a ampliar o debate sobre os problemas do desenvolvimento turístico para além da esfera econômica. Assim, colocar em evidência o Orientalismo como propagador de 
estereótipos e esses mesmos estereótipos utilizados pela indústria turística, fornece ao estudo dessa área uma construção histórica que não deve ser negada ou ignorada.

\section{Referências}

AUGRAS, Monique. Opinião pública: teoria e pesquisa. Petrópolis: Vozes, 1970.

BOTTON, Alain de. A arte de viajar. Rio de Janeiro: Intrínseca, 2012.

BURKE, Peter. Testemunha ocular: história e imagem. Bauru: EDUSC, 2004.

DEBORD, Guy. A sociedade do espetáculo. São Paulo: Contraponto, 1997.

DIAS, Reinaldo; CASSAR, Maurício. Fundamentos do marketing turístico. São Paulo: Pearson Prentice Hall, 2005.

HAUG, Wolfgang Fritz. Crítica da estética da mercadoria. São Paulo: UNESP, 1997.

LIPPMANN, Walter. Opinião pública. Petrópolis: Vozes, 2010.

MADUREIRA, Fernanda. O que fazer no Irã: descubra o que é indispensável em uma visita pelo país. 2016a. Disponível em: $<$ https://www.mochilando.com.br/o-que-fazer-no-ira-descubra-oque-e-indispensavel-em-uma-visita-pelo-pais/>. Acesso em: 18 jun. 2017.

MADUREIRA, Fernanda. Por que viajar para o Irã. 2016 b. Disponível em: <https://www.mochilando.com.br/viajar-para-oira/>. Acesso em: 18 jun. 2017. 
MOESCH, Marutschka. O fazer-saber turístico: possibilidades e limites de recuperação. In: GASTAL, S. (Org.). Turismo: 9 proostas para um saber-fazer. Porto Alegre: EdiPUC-RS, 2001.

NOVA, Cristiane. A "história" diante dos desafios imagéticos.

Projeto história 21: história e imagem. São Paulo, v. 21, p. 142162, nov. 2000.

OLIVEIRA, Antônio Pereira. Turismo e desenvolvimento: planejamento e organização. 4. ed. São Paulo: Atlas, 2002.

\section{OURIQUES, Helton Ricardo. A produção do turismo:}

fetichismo e dependência. Campinas: Alínea, 2005.

PEREIRA, Marcos Emanuel; ORNELAS, Tula. Estereótipos e destinos turísticos: o uso dos estereótipos nos folders de uma agência de fomento ao turismo. Caderno Virtual de Turismo, Rio de Janeiro, v. 17, p. 9-17, 2005.

SAID, Edward. Orientalismo: o Oriente como invenção do Ocidente. São Paulo: Companhia das Letras, 2007.

SIQUEIRA, Deis. História social do turismo. Brasília: Vieira, 2005.

URRY, John. O olhar do turista: lazer e viagens nas sociedades contemporâneas. 3. ed. São Paulo: SESC Studio Nobel, 2001.

VIAJANDO para o Egito, lugares surpreendentes para conhecer no país. Disponível em: <http://guiaviajarmelhor.com.br/viajandopara-o-egito-lugares-surpreendentes-para-conhecer-no-pais/>. Acesso em: 18 jun. 2017. 